\title{
Sociolinguistics Study on Taboos
}

\author{
Fan Mengxun* \\ Department of Foreign Language, Sichuan University of Science \& Engineering, Zigong city, Sichuan Province, \\ China.
}

*Corresponding Author: Fan Mengxun, Department of Foreign Language, Sichuan University of Science \& Engineering, Zigong city, Sichuan Province, China.

\begin{abstract}
Language should be used to learn is one of the research scope of pragmatics, in terms with science, the pragmatic comparative study between different language is a kind of commonly used research techniques. Context is one of the core concepts of pragmatics. Interpersonal communication depends on specific context, context directly affects the people to the use of words and reason. The appropriateness of some specific speech ACTS must be judged according to the context in which they are used. People have social attributes, and their lives are restricted and regulated by the society. People in social activities, often will encounter many sensitive issues, or embarrassing situation of difficult, this is taboo. It is like a free form the yoke of bondage in people's language and behavior. In the process of language communication, taboo people say or write some words or words, is a taboo language; Words that are forbidden or taboo to say or write are taboo words. Taboos are a reflection of human society and culture. As an inseparable part of language, taboos can be studied by pragmatics, that is, by comparing the taboos between different languages and understanding and expressing them in specific contexts. Sociolinguistics is a branch of linguistics that studies human language from the perspective of social status. Therefore, it opens up a new field for the study of "taboo phenomenon" in language. This paper attempts to make some superficial discussions on the formation and evolution of taboo words from the perspective of sociolinguistics. This paper mainly discusses the differences between Chinese and western cultures by comparing the similarities and differences in the categories of taboo words, so as to better understand and properly use taboo words in interpersonal communication.
\end{abstract}

Keywords: taboos, language, sociolinguistics.

\section{INTRODUCTION}

Taboo is a common cultural phenomenon among different nationalities in the world, which standardizes people's speech behavior and social communication. The huge cultural differences between China and the west directly lead to the differences in taboos between Chinese and English. Therefore, no matter in English or Chinese, we will encounter some words with strong aversion to each other due to different traditions or social customs. As a result, we should avoid using some words, namely, taboo words. By analyzing and elaborating the origin, definition, motivation and social function of taboo words, we can see the generality and particularity of social development, social values, moral values, as well as the nationality and commonality of culture.

With the rapid development of society, cross-cultural communication has become an important part of modern communication. A comparative study of English and Chinese taboos is helpful to understand the cultural connotation of language, avoid communication mistakes, and achieve the ideal communication effect, so as to make cross-cultural communication more appropriate. In addition, it can improve the appreciation and application level of English, and more importantly, it can understand the social psychology and customs and culture of Britain, America and other countries. Only through careful study of the general usage of taboo words in English and familiarity with their use can taboo words be more accurately understood and properly used. Therefore, studying and understanding English taboos is not only helpful to cultivate learners' awareness of cross-cultural communication, but also has some enlightening and guiding significance for English teaching and learning.

\section{LITERATURE REVIEW}

The early researches on taboos were relevant to anthropology, sociology, ethnography of 
communication and psychology, such as The Golden Bough (1890) by Sir James G Frazer, Totem and Taboo(1913) by Sigmund Freud, and Taboo, Truth and Religion (1967) by Franz Baermann Steiner, and so on (Asante, M.K. \& Newmark, E.\&Blake,1982). However, the most comprehensive research is made by Steiner, who not only offers the origin of taboo, but also its influence and functions, as well as the relationship between anthropology and psychology with theories.

Thanks to the emergence of sociolinguistics, studies about the relationship between language and society sprung up, and a great many sociolinguists take interest in exploring the importance of linguistic taboo, thus many researches have been conducted in the United States since the 1960s, such as R. A. Hudson's Sociolinguistics (1980), Peter Trudgill's Sociolinguistics, An Introduction to Language and Society (1983) and Ronald Wardhaugh's An Introduction to Sociolinguistics (1986), in which linguistic taboos are often discussed along with society, culture or euphemism (Li Junfu,2007).

In China, however, owning to the great influence of feudalist ideology, this topic is more strictly limited and studies about it appear later. Chen Yuan's monograph, Sociolinguistics (1982), is the earliest bibliography that offers an overall analysis of linguistic taboos; New Explorations on Language, Culture and Society (1986) by Chen Jianmin, makes further discussions from the perspective of the relationship between language and society; moreover, the work of Chinese Folk Linguistics (1992) by Qu Yanbin discusses taboos in Chinese in terms of folklores (Ding Ling, 2006). In addition, more articles about taboos gradually appear since the 1980s.

\section{THE ORIGIN AND DEVELOPMENT OF TABOO}

The word "taboo" originates from Polynesia. British navigator Captain James Cook came to the Tonga islands while exploring the south Pacific in the 8th century. He found that the customs on the island were strange and there were many taboos. For example, certain things were allowed to be used by certain figures such as gods, Kings, monks and chiefs, but not by ordinary people. Some places and some people are not accessible; Certain names and words are absolutely taboo, and all who are regarded as sacred or unclean are forbidden. Whoever commits a taboo will be punished by supernatural forces. The islanders call this taboo as "tabu". In fact, tabu does not directly mean "taboo" in Tongan, meaning "sacred". Cook and subsequent explorers brought tabu back to England, making it part of the English vocabulary. Tabu has since moved into other languages, becoming an international word. English is mostly written as taboo, except spelled tabu in anthropology. This kind of taboo phenomenon is not unique to Tonga islands. Similar phenomenon exists more or less all over the world. It is said that captain cook was later killed by natives in the Hawaiian islands for violating local taboos. Linguistic taboos, which are reflected in language, are ubiquitous in various languages.

In the early days of human civilization, people did not dare to casually mention those words indicating death and disaster to avoid disaster. These words that people "keep at a respectful distance" in language communication are the earliest taboo words. With the improvement of human civilization, people pay more and more attention to the use and expression of language, and try their best to avoid psychological and emotional harm to others. As a result, many taboos are generated, which promotes the development of taboos. Later, it was widely used as a special term in anthropology, ethnology and sociology. Taboo words usually refer to people who are unable, afraid or unwilling to speak for some reason in social occasions. With the increasing frequency of cultural communication in today's society, taboos have become a problem that people need to pay attention to in cross-cultural communication. Otherwise, communication failure will be caused by different taboos. There must be cultural differences between people with different cultural backgrounds. The embarrassing phenomenon of communication activities caused by this difference is very common. Some foreigners feel embarrassed to ask Chinese people personal questions such as their age, marriage and income when they meet for the first time, while Chinese same-sex friends walking on the street arm in arm attract strange looks from foreigners. These phenomena suggest that it is not just language that causes cultural isolation. The taboo difference between Chinese and western is the direct cause of the above communication awkwardness.

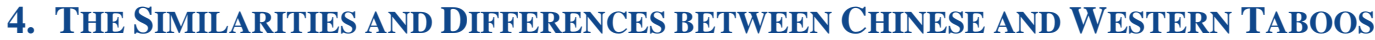

With the rapid development of society, cross-cultural communication has become an important part of modern communication. If you violate language taboos in communication, it will appear abrupt and rude, and will easily cause serious consequences. Therefore, both China and the west attach great 
importance to the use of taboo words. So how can we avoid these mistakes? Only by being familiar with the use of Chinese and western taboos and understanding their similarities and differences can we understand and use taboos more accurately and ensure that cross-cultural communication can be carried out qualitatively and quantitatively.

Due to the differences in ethnic cultural backgrounds, there are some differences in the contents of language taboos. The differences between Chinese and western taboos are mainly reflected in the following aspects:

\subsection{Taboos Concerning Naming and Appellation}

Appellation is the appellation of certain people in certain interpersonal relationships. As a kind of social etiquette, this name can always reflect the relationship between people in a certain social culture, which is the product of a specific culture. Due to the differences between Chinese and western cultures, there are huge differences in customs and taboos of names and appellations as cultural symbols of interpersonal relations. Influenced by Christianity, western society and culture,they think "All men are created equal". , so in terms of appellation is not as much as Chinese scruples. For those who are close to each other, they can be called by their first names even between their elders and their superiors. This does not disrespect each other, but shows that people are equal, cordial, friendly relations. There are only a few occupations or occupations that can be used as titles, such as Doctor, Judge, Professor, President and so on. In Britain and America, it is very common for the younger generation to follow the elder's name. British prime minister Winston Churchill's father was Randolph Churchill, the prime minister's son was also named Randolph Churchill, grandfather and grandson of the same name. President Franklin Roosevelt's son was also named Franklin Roosevelt. Obviously, this concept is quite different from the traditional customs of our country. In most Chinese families, children are not allowed to call their parents or elders by their given names. In particular, it is taboo for younger people to share the same name with their elders or to have homo phonic or characters in their names. To do otherwise would be considered "unfaithful" and "rude."

\subsection{Taboos Concerning Privacy}

People in western countries attach great importance to privacy, which has a lot to do with the sacrosanct social system of private ownership promoted by the west. There is A saying in English: A man's home is his castle. It means that one's home is sacred and cannot be entered without permission. The same is true of personal private life. For most Britons and Americans, questions such as how old they are, how much they earn, whether they are married, what they do for a living, their political leanings and religious beliefs are sensitive.

Therefore, in the west, it is regarded as impolite behavior to ask others' privacy. To avoid privacy, westerners will choose some trivial topics to talk about, such as the weather and football matches. Unless they say they don't mind, it's considered an invasion of privacy. However, Chinese people think these are everyday topics and there is nothing wrong with talking about them. The reason is that Chinese people are not familiar with privacy as understood by westerners, and there is no word equivalent to privacy in Chinese. The meanings of privacy in English include "privacy", "privacy", "privacy", "seclusion", "solitude", "reluctance to be interfered by others", and "reluctance to be interfered by others". For thousands of years, Chinese people live in the same place and have a lot of contacts. It is difficult for them not to be known or interfered in their personal life or private affairs. In addition, Chinese people have the spirit of solidarity, which makes people rarely have personal privacy. In contrast, private lives can be maintained in the west, where individuals live alone and do not interfere. Thus, it can be seen that the cultural difference between Han people's emphasis on collective and English-speaking people's emphasis on individual privacy has generated some taboo topics in language. However, due to such differences, there are many misunderstandings in crosscultural communication, and Chinese people's well-intention-ed concern is misunderstood by westerners as snooping and infringing on privacy.

\subsection{Taboos Concerning Numbers and Colors}

There are taboos about Numbers in both English and Chinese. Chinese people avoid the number four because it sounds the same as the Chinese word for die. All Numbers, including telephone Numbers, license plate Numbers, door Numbers, etc., as long as the number with "four" fewer people. "Five" is a taboo number in the month. May is considered an "evil month", and May 5th is an especially 
unlucky day. "Nine" is a taboo number in age. There is an ancient saying that "nine in the Ming dynasty and nine in the dark are either death or illness." The so-called "Ming nine" refers to the number with nine, such as nine, nineteen, twenty-nine, etc. Dark nine refers to multiples of nine, such as $18,27,36$, etc. People don't talk about their age, but in a euphemistic way. A 36-year-old will say he is 35 years old or 37 years old next year. The taboo number in English is thirteen, because the bible says that Judas who betrayed Jesus was the thirteenth person at the table, so people don't like thirteen. The hotel doesn't have room 13; The sailors refused to sail on the thirteenth; Important activities should be avoided on the 13th.

Red is the basic worship color in Chinese culture, which reflects the spiritual and material pursuit of Chinese people. It symbolizes good luck and happiness, such as the people who promote the good marriage of others called matchmaker, festive days to hang red lanterns, paste red couplets, red words of happiness; When the male marries the female to marry sticks the big red happy word, calls the lively, prosperous red fire; Describe the bustling, lively place called red dust; It also symbolizes revolution and progress. For example, the initial regime of the communist party of China was called "red regime", and the earliest armed forces were called "red army". It is also a symbol of success, success, such as people's circumstances is very good known as red, red very temporarily, get the boss favorite called red, divided into partnership profit called dividends, to send bonuses to send red envelopes and so on; It also symbolizes beauty, beauty, such as refers to the woman Sheng makeup for red makeup or red outfit, the woman known as red sleeves, refers to the woman's beautiful appearance for the confidant. In western culture, red is a derogatory word, which is associated with fire and blood. It symbolizes brutality and bloodshed, such as (1) The red rules of tooth and claw, (2) red revenge and (3) a red battle. It also symbolizes radical and violent revolution, such as (1) a political movement with fierce red hot political campaign, (2) a red revolution, (3) radical leftist activities. It also symbolizes danger and tension, such as (1) red alert air raid alarm, (2) a red adventure story, (3) a red flag danger signal flag. It also symbolizes dissolute and obscenity, such as (1) a red waste of his youth, (2) a red light district, (3) Is she really so red as she Is painted? Is she so dissolute as she is portrayed to be?

Although English and Chinese belong to two different cultural backgrounds, through comparison, we can find that there are many similarities between Chinese and western taboos in expression, which are mainly reflected in the following aspects:

\subsection{Taboos Concerning Religion}

It is difficult for people to escape from the barriers of religious culture. Ignorance leads to blind worship of any incomprehensible natural and social phenomena, and even deification of things closely related to religious meaning in language expression. The name of a god is seen as having superhuman power, as is the entity. In this way there is bound to be a feeling of humility and natural obedience, and to leave their own affairs in the hands of god. With the development of thinking, the concept of animism and immortality of the soul is increasingly deepened, and the worship of religion and the fear of ghosts and gods are bound to produce various taboos. Reflected in the language is to try to use a clever way, avoid offending the gods, do not respect the gods, unlucky words do not say, or find a respectful, auspicious words to replace, otherwise it is treason, blasphemy. Lord, creator, the All Mighty, the Lord of lords, the king of Kings and others are obvious examples. The same is true of China. Early China was a country worshiped by many gods. Totem worship, ancestor worship to human religion is all-encompassing. Because of worship, people have created many taboos on many cults, especially the name of the cult. For example, the mountain people in the northern forest areas of China have the custom of using tigers as gods. They are afraid to call the name of the tiger and rename it "Mountain God"; some places in Anhui have the custom of using fox as a god. The locals do not dare to call their names, but they are called "Xian'gu"; For example, if you buy a portrait of God of Wealth, you can't say "buy", you can only say "please"; when you sell, you also say "send a wealthy god" instead of "selling the god of wealth."

\subsection{Taboos Concerning Human and Human Physiological Behavior}

In Chinese and western culture, there is a taboo mentality towards some specific human parts and human physiological behaviors, especially the words about sexual behaviors and sexual organs are the most taboo. Such as words (dick, fuck, etc) can only be used between people who are very close to each other or in a medical context. In addition to tears and sweating, other excretion terms can be 
embarrassing or unpleasant to hear and thus taboo. For example, "pregnancy" is related to sexual behavior, so both English and Chinese express "pregnancy" in a euphemistic way. Having a baby is such a big deal for Chinese people that when someone is pregnant in Chinese, they say, "she has a baby," "she is having a baby," or "she is going to be a mother." In English, they say: "she is expecting"; "She is well -- along"; "She is in a delicate condition."

\section{CONCLUSION}

To sum up, a comparative study of English and Chinese taboos is helpful to understand the cultural connotation of the language, avoid communication mistakes and achieve the ideal communication effect, so as to make cross-cultural communication more appropriate. In addition, it can improve the appreciation and application level of English, and more importantly, it can understand the social psychology and customs and culture of Britain, America and other countries. At the same time, it is helpful to cultivate learners' awareness of cross-cultural communication, and has certain inspiration and guiding significance for English teaching and learning.

\section{REFERENCES}

[1] Claire Kramsch. Language and Culture. 上海: 上海外语教育出版社2000.

[2] Elizabeth Gage. Taboo, London: Corgi Books 1993.

[3] Wallace B. Alan. The Taboo of Subjectivity: Toward a New Science of Consciousness, Oxford: New York: Oxford University Press 2000.

[4] 陈 原. 语言与社会生活[M]. 三联书店, 1980.

[5] 邓炎昌,刘润清. 语言与文化[M]. 北京: 外语教学与研究出版社, 1991.

[6] 葛校琴. 英汉语言禁忌的深层文化映现[J]. 外语与外语教学, 2001, (2):39-41.

[7] 顾嘉祖,陆 异. 语言与文化[M]. 上海: 上海外语教育出版社, 2002.

[8] 贾玉新. 跨文化交际学[M]. 上海: 上海外语教育出版社, 2004.

[9] 李桂媛. 英汉禁忌语及委婉语探讨 [J]. 天津外国语学院学报, 2004,(5):5-8.

[10] 刘润清. 外语教学中的科研方法[M]. 外语教学与研究出版社, 1999.

Citation: Fan Mengxun. "Sociolinguistics Study on Taboos". International Journal of Humanities Social Sciences and Education (IJHSSE), vol. 7, no.1, 2020, pp. 88-92. doi: http://dx.doi.org/10.20431/2349-0381.07 01010.

Copyright: (C) 2020 Authors. This is an open-access article distributed under the terms of the Creative Commons Attribution License, which permits unrestricted use, distribution, and reproduction in any medium, provided the original author and source are credited. 